REV. 1

\title{
GUIDANCE DOCUMENT FOR Preparing Water Sampling ANd ANALYSIS Plans For UMTRA PROJECT SITES
}

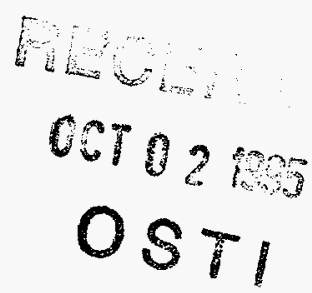

September 1995

\section{DISCLAIMER}

This report was prepared as an account of work sponsored by an agency of the United States Government. Neither the United States Government nor any agency thereof, nor any of their employees, makes any warranty, express or implied, or assumes any legal liability or responsibility for the accuracy, completeness, or usefulness of any information, apparatus, product, or process disclosed, or represents that its use would not infringe privately owned rights. Reference herein to any specific commercial product, process, or service by trade name, trademark, manufacturer, or otherwise does not necessarily constitute or imply its endorsement, recommendation, or favoring by the United States Government or any agency thereof. The views and opinions of authors expressed herein do not necessarily state or reflect those of the United States Government or any agency thereof. 


\section{INTENDED FOR PUBLIC RELEASE}

This report has been reproduced from the best available copy. Available in paper copy and microfiche.

Number of pages in this report: 46

DOE and DOE contractors can obtain copies of this report from:

Office of Scientific and Technical Information

P.O. Box 62

Oak Ridge, TN 37831

(615) 576-8401

This report is publicly available from:

National Technical Information Service

Department of Commerce

5285 Port Royal Road

Springfield, VA 22161

(703) $487-4650$ 


\section{DISCLAIMER}

Portions of this document may be illegible in electronic image products. Images are produced from the best available original document. 
GUIDANCE DOCUMENT FOR PREPARING

WATER SAMPLING AND ANALYSIS PLANS

FOR UMTRA PROJECT SITES

September 1995

Prepared for

U.S. Department of Energy

Environmental Restoration Division

UMTRA Project Team

Albuquerque, New Mexico

Prepared by

Jacobs Engineering Group Inc.

Albuquerque, New Mexico 
TABLE OF CONTENTS

Section

Page

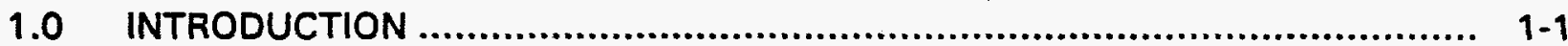

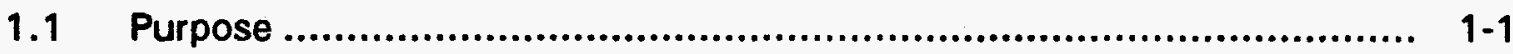

1.2 Previous work ............................................................... $1-1$

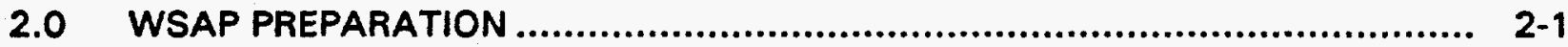

2.1 WSAP Review memo and updates .......................................... $2-1$

2.2 WSAP Section details............................................................ $2-3$

2.2.1 Introduction (Section 1.0) ............................................. 2-3

2.2.2 Site Conditions (Section 2.0) .......................................... 2-6

2.2.3 Data Collection Objectives (Section 3.0)............................... 2-11

2.2.4 Data Quality Requirements (Section 4.0) ............................. 2-13

2.2.5 Sampling Plan (Section 5.0) ........................................ 2-14

2.2.6 List of Contributors (Section 6.0) ................................... 2-15

2.2.7 References (Section 7.0) .......................................... 2-15

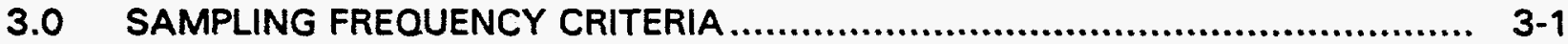

3.1 Regulatory requirements ..................................................... $3-1$

3.2 Hydrologic factors................................................................ 3-1

3.2.1 Ground water flow rates .................................................. 3-1

3.2.2 Water quality............................................................ $3-2$

3.2.3 Seasonal effects ........................................................ $3-3$

3.2.4 Surface water sampling ............................................. 3-6

3.3 Geochemical considerations ............................................... 3-7

4.0 SAMPLING LOCATION SELECTION CRITERIA ..................................... $4-1$

4.1 Regulatory requirements ..................................................... 4-1

4.2 Hydrologic factors.................................................................. 4-1

4.3 Geochemical considerations ...................................................... 4-2

5.0 ANALYTICAL PARAMETER SELECTION CRITERIA ................................. $5-1$

5.1 Regulatory requirements ....................................................... $5-1$

5.2 Contaminants of concern................................................... $5-1$

5.3 Indicator parameters .......................................................... $5-3$

5.4 Geochemical requirements .................................................... $5-3$

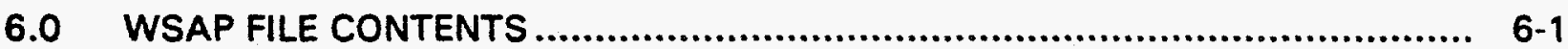

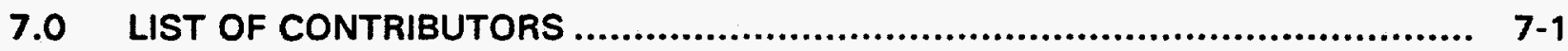

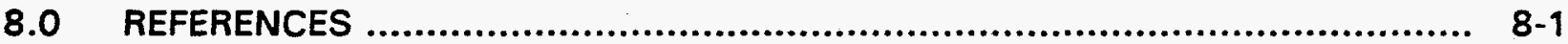




\section{LIST OF FIGURES}

Figure

Page

3.1 Schematic of monitoring well locations and extent of contamination

$3-4$

3.2 Sulfate concentrations in monitor wells at the theoretical site shown on

Figure 3.1

\section{LIST OF TABLES}

Table

Page

2.1 Table of contents for WSAPs for UMTRA Project sites...............................

$2-2$

5.1 Ground water standards for UMTRA Project sites ................................ $5-2$ 


\section{LIST OF ACRONYMS}

Acronym

$A C L$

BLRA

COC

DO

DOE

EPA

LTSP

$\mathrm{MCL}$

ORP

QA

QC

RAP

RI/FS

SOP

SOWP

TAC

TAD

UMTRA

UMTRCA

UPDCC

WSAP

\section{Definition}

alternate concentration limit

baseline risk assessment

contaminant of concern

dissolved oxygen

U.S. Department of Energy

U.S. Environmental Protection Agency

long-term surveillance plan

maximum concentration limit

oxidation/reduction potential

quality assurance

quality control

remedial action plan

remedial investigation/feasibility study

standard operating procedure

site observational work plan

Technical Assistance Contractor

Technical Approach Document

Uranium Mill Tailings Remedial Action

Uranium Mill Tailings Radiation Control Act

UMTRA Project Document Control Center

water sampling and analysis plan 


\subsection{INTRODUCTION}

\subsection{PURPOSE}

A water sampling and analysis plan (WSAP) is prepared for each Uranium Mill Tailings Remedial Action (UMTRA) Project site to provide the rationale for routine ground water sampling at disposal sites and former processing sites. The WSAP identifies and justifies the sampling locations, analytical parameters, detection limits, and sampling frequency for the routine ground water monitoring stations at each site.

This guidance document has been prepared by the Technical Assistance Contractor (TAC) for the U.S. Department of Energy (DOE). Its purpose is to provide a consistent technical approach for sampling and monitoring activities performed under the WSAP and to provide a consistent format for the WSAP documents. It is designed for use by the TAC in preparing WSAPS and by the DOE, U.S. Nuclear Regulatory Commission, state and tribal agencies, other regulatory agencies, and the public in evaluating the content of WSAPs.

The format for the WSAP documents and the contents of each section are described in Section 2.0. Section 3.0 provides guidance for determining sampling frequencies, Section 4.0 discusses criteria to be used in selecting sampling locations, and Section $\mathbf{5 . 0}$ contains criteria for selecting analytical parameters. Guidance for the contents of each site's WSAP file is presented in Section 6.0, the list of contributors is in Section 7.0, and the references used to prepare this document are listed in Section 8.0.

\subsection{PREVIOUS WORK}

The WSAP guidance document was initially published in September 1993; WSAPS were generated for most of the UMTRA Project sites during fiscal year 1994 (1 October 1993 through 30 September 1994). The DOE and the WSAP authors have recommended changes to the format and content of the WSAP documents since the first guidance document was published. This revision of the WSAP guidance document is in response to those recommendations. The primary changes are as follows:

- Each WSAP document will be reviewed at least once a year. WSAPs will be updated as needed, instead of annually. The WSAP documents may be revised as a result of changes in the interpretation of the site conceptual model, regulatory requirements, or other criteria that affect the approach to water sampling and monitoring activities.

- The WSAP documents will contain the plan for routine, periodic ground water sampling activities only. Unique or specialized sampling events (such as sampling for geochemical characterization or risk evaluation) will not be included in the WSAP documents. 
- The revised WSAP documents will include a detailed sampling plan for the upcoming 2-year period, projected sampling requirements for an additional 5-year period, and a proposed end point for routine sampling and monitoring activities. The 1993 WSAP guidance document required a description of the upcoming sampling requirements for 1 year. 


\subsection{WSAP PREPARATION}

The WSAP is a relatively brief but comprehensive document consisting of about 20 pages of text and 20 pages of tables and figures. Applicable sections of standard operating procedures (SOP) (JEG, n.d.), other guidance documents, regulations, and reports should be referenced. However, extended summaries of technical information should be included when necessary to provide clarification to specific WSAP elements. Hydrogeologic and site operational history information are presented in the site conceptual model. The regulatory requirements and site conceptual model are used to identify the sampling locations, frequency, and analytes for the recommended monitoring periods. The WSAP table of contents is shown in Table 2.1.

The WSAP consists of five major sections. The introduction (Section 1.0) provides the WSAP's purpose, a summary of the site operational history, the regulatory status of the site, and a summary of the sampling plan for the upcoming 2 years. Site conditions (Section 2.0) includes a technical presentation of site hydrogeologic characteristics, the specific site operations that caused (or could cause) ground water contamination, and an evaluation of water quality results, including the presence or absence of trends in water quality. The site conceptual model is presented as the summary to Section 2.0. The data collection objectives (Section 3.0) are the regulatory and technical reasons for collecting the samples. Data quality requirements are presented in Section 4.0. The information, discussions, data evaluations, and conclusions in Sections 1.0 through 4.0 support the sampling recommendations presented in Section 5.0. Each WSAP will provide a detailed sampling plan for the upcoming 2-year period, projected sampling requirements for an additional 5-year period, and a proposed end point for routine ground water sampling and monitoring.

\subsection{WSAP REVIEW MEMO AND UPDATES}

Each WSAP document will be reviewed at least once a year. The annual WSAP review will be documented by the primary author (site hydrologist) in a memo to the DOE (through the TAC technical manager and site manager) and will state either the need to revise the document or the appropriateness of the existing WSAP.

During fiscal year 1995, the WSAPs for most of the sites were reviewed. This review resulted in the publication of a WSAP supplement, consisting of a 5 to 10 page report modifying sampling frequencies, locations, and analytes (where appropriate), and providing the 2-year and 5-year sampling plan recommendations. The WSAP supplements were a one-time measure to bring existing WSAPs into conformance with the guidance provided in this guidance document. Supplements are identified with an " $S$ " as the last digit in the document number. Annual WSAP reviews must include a review of the supplement, when applicable.

WSAP revisions may result from an evaluation of the site analytical database (e.g., the need may arise to evaluate data anomalies or an exceedance of a water quality standard) or from a change in regulatory requirements that would affect routine sampling activities. A change in the interpretation of site hydrogeologic factors 
Table 2.1 Table of contents for WSAPs for UMTRA Project sites

1.0 INTRODUCTION
1.1 Purpose
1.2 Site location
1.3 Site history
1.4 Site status
1.5 Sampling plan summary

\subsection{SITE CONDITIONS}

2.1 Site background information

2.1.1 Surrounding land use

2.1.2 Surrounding water use

2.1.3 Contaminant sources

2.2 Geology and hydrology

2.2.1 Physical setting

2.2.2 Geology

2.2.3 Ground water hydrology

2.2.4 Surface water hydrology

2.3 Water quality

2.3.1 Background water quality

2.3.2 Point of compliance

2.3.3 Contaminant delineation

2.3.4 Surface water sampling locations

2.4 Site conceptual model

3.0 DATA COLLECTION OBJECTIVES

3.1 Regulatory requirements

3.2 Compliance monitoring

3.3 Site characterization

3.4 Other considerations

4.0 DATA QUALITY REQUIREMENTS

5.0 SAMPLING PLAN

5.1 Sampling locations

5.2 Analyte selection

5.3 Sampling frequency

5.4 Data evaluation methods

5.5 Response to anomalous data

6.0 LIST OF CONTRIBUTORS

7.0 REFERENCES 
could also affect routine sampling activities and, therefore, a revised WSAP would be required.

\subsection{WSAP SECTION DETAILS}

The content and purpose of each WSAP section are described in Sections 2.2.1 through 2.2.7. Where appropriate, wording from each description can be incorporated into the WSAPs using site-specific information (such as site name and location). This wording appears in italics. The reference to "Section" in parentheses following each heading refers to the section number of the site-specific WSAP. Where appropriate, the following subsections also describe figures and tables that should appear in the site-specific WSAP.

References for the information sources used in each WSAP are an important part of each document. This will allow the author of the WSAP to summarize the applicable sections from the sources (in an effort to keep the WSAP brief) and will allow the reader to locate the source documents for additional information.

\subsubsection{Introduction (Section 1.0)}

The WSAP introduction consists of five subsections: Purpose, Site Location, Site History, Site Status, and Sampling Plan Summary. The format and content of each subsection are described below. The figures and tables that should be included with these subsections are listed at the end of Section 2.2.1 of this guidance document.

\section{Purpose (Section 1.1)}

The following two paragraphs present the purpose for each site-specific WSAP and the purpose of the sampling and analyses described within each WSAP. With minor modifications for site-specific references and sampling requirements, it can be used as the opening paragraphs of each document.

Planned, routine ground water sampling activities at the U.S. Department of Energy (DOE) Uranium Mill Tailings Remedial Action (UMTRA) Project site in (insert site location (the sitel) are described in this water sampling and analysis plan (WSAP). The following plan identifies and justifies the sampling locations, analytical parameters, detection limits, and sampling frequencies for the routine. monitoring stations at the site. The ground water data are used for [site characterization and/or cell performance monitoring].

The regulatory basis for routine ground water monitoring at UMTRA Project sites is derived from the U.S. Environmental Protection Agency (EPA) regulations in 40 CFR Part 192 11995). Sampling procedures are guided by the UMTRA Project standard operating procedures (SOP) (JEG, n.d.), the Technical Approach Document (TAD) (DOE, 1989), and the most effective technical approach for the site. 


\section{Site Location (Section 1.2)}

The site location section is one paragraph that presents the following information:

- State, county, section, township, and range for the site.

- The distance and direction to the nearest town and city.

- The distance, direction, and route from the site to the closest highway and highway intersection.

State plane coordinates and latitude and longitude of the approximate center of the site (optional).

The above information should be displayed on a figure. In addition, an aerial photograph should be provided whenever possible.

For sites where the disposal cell is separate from the former processing site, the site location section will have two parts: one describing the location of the former mill site, and one describing the location of the disposal cell. This information should be shown on a figure. If an aerial photograph is provided, this information may be indicated on the aerial photograph.

\section{Site History (Section 1.3)}

This section describes the history of site ownership and site operations that resulted in site contamination. For processing sites, the following information is necessary:

- The types of ore and the processing chemicals and their byproducts.

- The source of water for mill supply and approximate amounts of water used.

- The approximate amount of wastewater discharged from the mill, stated in units of gallons, cubic feet, and acre-feet (and their metric equivalent, liters and cubic meters).

- The dates and areas for processing, ore storage, raffinate ponds, lagoons, and tailings disposal, including approximate volumes discharged to each.

- Any other surface or ground water use that may have affected lor is currently affecting) water flow and/or contaminant movement in the vicinity of the site.

The disposition of the tailings is also described in this section, providing information on the location of disposal areas. The tailings may have been moved off the site, stabilized in place, or stabilized on the site. Tailings disposal areas, ore storage areas, the source(s) of mill supply water, and waste water disposal areas should be 
shown on one or more figures. This information may also be indicated on an aerial photograph.

Limiting the discussion of site history to items that have caused or may potentially cause ground water contamination will allow this section to remain brief and within the scope and purpose of the WSAPs. Sources used should be referenced to direct the reader to additional information. It is not necessary to describe the former locations of buildings or other detailed descriptions of site history unless those items have a significance regarding site contamination.

\section{Site Status (Section 1.4)}

Site status provides the regulatory status of the site, the status of remedial activities, and the status of major documents prepared for or in preparation for the site. For example, this section states whether surface remediation is pending, under way, or completed. It also describes the status of the remedial action plan (RAP), site observational work plan (SOWP), long-term surveillance plan (LTSP), baseline risk assessment (BLRA), and other appropriate site documents.

\section{Sampling Plan Summary (Section 1.5)}

This section is a summary of Section 5.0 of the WSAP, which provides the detailed recommendations and supporting discussions for the sampling activities. It presents the recommended sampling locations, frequencies, and analytical parameters for the upcoming 2 years, a brief description of the projected routine sampling requirements for an additional 5 years, and the end point for routine ground water sampling. The sampling locations should be shown on one or more figures. References to these figures and a table listing the locations and analytical parameters should also be included in this section.

Section 1.0 of the WSAP includes the following figures:

- The general site vicinity on a map that shows the approximate location within the state plus nearby landmarks, county lines, and highways and towns referenced in the text.

- A detailed site vicinity map that includes county, section, township, and range lines, plus the routes of site ingress and egress. Also included on this map (or on an additional map) are residential areas (if present), surrounding water use locations (which include surface water intakes, domestic wells, irrigation wells, and public supply wells), surface water sampling locations, and the surface discharge area for each potentially affected aquifer. If the text includes references to state plane coordinates and latitude/longitude lines, the map should include them.

- A detailed map showing the site in its present condition and including all existing and decommissioned monitor, domestic, irrigation, and public supply wells. 
- Routes of ingress and egress to each monitor well, showing property boundaries and current property owners.

Section 1.0 contains a table listing all wells and identifying the following:

- Screened, cased, and sand-packed intervals.

- Type of well (e.g., point-of-compliance, background, contaminant delineation).

- The hydrogeologic unit monitored.

- Data logger locations and type.

- Measuring point elevation.

- Ground surface elevation.

- Casing type and diameter.

- Well status (existing or decommissioned).

\subsubsection{Site conditions (Section 2.0)}

Section 2.0 of the WSAP describes and evaluates the site location, surrounding land use, surrounding water use, hydrogeologic conditions, and the nature and extent of contamination. This information, which provides the technical basis for recommended sampling, should be presented concisely. Additional guidance for the development of this section can be found in Remedial Investigation/Feasibility Study (RI/FS): Process, Elements, and Techniques (DOE, 1993).

The review and evaluation of data previously collected may indicate the need for additional investigations. However, recommendations for additional work are not within the scope of the WSAP. Therefore, statements regarding data gaps, additional data needs, or recommendations for additional work are not included in a WSAP. They should, however, be documented for the TAC site manager in the form of a separate memo with the technical manager's concurrence.

\section{Site Background Information (Section 2.1)}

\section{Surrounding Land Use (Section 2.1.1)}

This section is a one-paragraph description of the land uses in the vicinity of the site, ownership and control of the site and surrounding areas, the direction to and proximity of the nearest residences, and the population of nearby towns and cities. 


\section{Surrounding Water Use (Section 2.1.2)}

This section is a one- or two-paragraph description of the sources of water used to support the surrounding land uses described above, including the nearby communities and residences.

\section{Contaminant Sources (Section 2.1.3)}

This section focuses primarily on the aspects of site operations that caused or could cause contamination of ground water.

\section{Geology and Hydrology (Section 2.2)}

\section{Physical Setting (Section 2.2.1)}

This section is a one- to two-paragraph description of the topographic and geomorphologic features of the site and surrounding areas. Surface water drainage, ground water recharge areas, and ground water discharge areas should be included in the descriptions. A physiographic features map or topographic map should be referenced as a figure with man-made structures indicated which may have altered the geology or hydrology near the site(s) (e.g., a gravel pit). LTSPs or RAPs contain most of the necessary information, but the WSAP author may need to modify the applicable sections from those reports or provide additional information.

Because topographic and geomorphologic features are a result of geologic structure, stratigraphy, sediment deposition, and erosion, this section should provide insight into features that may influence ground water flow paths. For example, alluvial deposits may be heterogeneous and anisotropic due to layering and interfingering of gravel, sand, and clay beds, but eolian deposits may be relatively homogeneous. The presence of terraces may indicate areas of ground water discharge in the form of seeps along escarpments. The presence and identification of these and manmade features can have an effect on the recommended sampling strategy.

\section{Geology (Section 2.2.2)}

This section identifies the names, ages, and physical properties of the geologic formations (rock units) within the area of the site. Additionally, site-specific geology is correlated with regional geologic information. Descriptions of the geologic framework should include all units from ground surface to one or two units below the affected water-bearing zone or the aquifer in use within the region, whichever is deeper. Included in the description for each aquifer and confining unit are the composition of the matrix materials (grain size and distribution, mineralogy, porosity, cementation and cementing material composition, and the presence or absence of fractures), the type of sediment deposition that formed the geologic units, and the strike and dip of the units. The text for this section should be limited to one page; descriptions of the geologic units can be in the form of one geologic unit per bulleted item. 
In accordance with the TAD (DOE, 1989), data sources such as well logs, reports, and maps should be used to prepare the geologic descriptions. The information can be obtained from site documents, but should be reviewed for consistency between the documents, and any new information that may be available should be added to the descriptions. Attachment 2 of the RAP for each site is generally a good starting point for the geologic information. Site well logs are filed in the UMTRA Project Document Control Center (UPDCC).

Figures accompanying this section are a regional stratigraphic column or regional cross section that shows geologic and hydrologic names and at least two site-specific geologic cross sections based on lithologic logs from monitor wells and other known information. The site-specific cross sections should show water levels in each well and be parallel with and perpendicular to the direction of ground water flow. The vertical exaggeration of the cross sections should be kept to a minimum and clearly identified. The cross sections should encompass the entire extent of ground water contamination known or anticipated.

\section{Ground Water Hydrology (Section 2.2.3)}

This section should be limited to about one page of text. It describes the names, correlation with geologic units, physical properties, and hydraulic properties of each water-bearing and confining unit. Each unit from ground surface to the confining unit below either the deepest affected aquifer or the aquifer in use in the area (whichever is deepest) is included. This section contains figures showing piezometric surfaces for different zones and seasons, which include specific references to the dates of the measurements and the screened and sand-packed intervals of the wells used to construct the figures. The hydrologic unit descriptions can be presented as bulleted items.

The hydraulic properties presented include the following:

- Hydraulic conductivity, transmissivity, porosity, and effective porosity (if known).

- Ground water flow direction (horizontal and vertical).

- Ground water flow velocity (horizontal and vertical).

- Seasonal water-level fluctuations (in graphic and narrative form) for each waterbearing zone and confining unit.

The range of the different hydraulic properties should be presented with references to the source of data.

The following additional information should be included:

- The type and location of the recharge and discharge areas for the aquifers. 
- The stage of nearby rivers.

- Ground water and surface water interactions.

- Municipal and irrigation pumpage (for both surface water and ground water).

The WSAP author may need to construct graphs of water level fluctuations in the different zones monitored by the monitor well network. Records of water levels (presented as tables and graphs) from data loggers should be included in this section.

All existing data should be evaluated for consistency with the hydraulic and geologic properties of the aquifers and confining units. For example, the hydraulic conductivity of a water-bearing unit consisting of a well sorted, medium-grained sand may have been reported as $1 \times 10^{-5}$ centimeters $(\mathrm{cm})$ per second from an average of slug test data. However, this figure may be unreasonably low, based on a published range of about $1 \times 10^{-3} \mathrm{~cm}$ to $1 \mathrm{~cm}$ per second for the hydraulic conductivity of medium-grained sand (Freeze and Cherry, 1979).

This potentially unrepresentative hydraulic conductivity will affect transmissivity and velocity estimates. Identification of potential errors or recommendations for additional work are not the purpose of the WSAP. However, existing data should be presented along with a realistic interpretation of the data, including a calculation for the average linear ground water velocity based on a literature value for hydraulic conductivity.

\section{Surface Water Hydrology (Section 2.2.4)}

This section is a one- or two-paragraph description of surface water features. Figures show major drainage features on and around the site, local springs or seeps, and streams or rivers in the site vicinity. The characteristics of each feature (e.g., a perennial stream, a losing or gaining stream, or approximate flow rates and periods of flow for springs and rivers) should be explained relative to ground water flow and site-related contaminant movement. Information recorded by data loggers (in wells and stream gauges) would be useful in preparing this section.

\section{Water Quality (Section 2.3)}

Water quality results (ground water, surface water, and results from geochemical data loggers, if installed) from previous sampling events are presented in this section. The information is used with the preceding sections to provide the technical basis for sampling recommendations (presented in Section 5.0) for the upcoming 2 years. The data require compilation and interpretation by the WSAP preparation team (site hydrologist, geochemist, and toxicologist).

There are up to four subsections as follows: Background Water Quality (Section 2.3.1), Point of Compliance (Section 2.3.2), Contaminant Delineation (Section 2.3.3), and Surface Water Sampling Locations (Section 2.3.4). Well designations 
from previous reports (with screened and gravel-packed intervals) should be presented, along with any modifications to the designations that the WSAP author feels are justified based on a reinterpretation of older data or an interpretation of recent data. For example, if a well was previously reported as a background well but is clearly within the path of ground water contamination, the designation should be changed to a contaminant delineation well.

The information within each subsection is organized to present the water quality, geochemistry, and evaluation of any trends using the existing database. Water quality describes the constituents and range in concentrations and detection limits. The geochemistry portion graphically presents the data on trilinear diagrams or Stiff diagrams to show water quality information and to categorize the different water quality types present. Water quality also should be categorized by total dissolved solids content, $\mathrm{pH}$, and oxidizing or reducing potential. If applicable, a comparison to limited use ground water (40 CFR Part 192) should be made. Distinctions between filtered and unfiltered sample results are also necessary.

The data within each category (i.e., background wells, point-of-compliance wells, contaminant delineation wells, and surface water) are also evaluated for trends. The first step is to plot water quality versus time, and water levels versus time, for each well and surface water sampling location. This should also be done for sampling locations that may no longer exist, because those data may be useful in establishing the existence of a trend. Again, distinctions between filtered and unfiltered results are necessary.

The trend analyses should be performed with the assistance of the site statistician and geochemist. Because each site and data set are different, it is difficult to provide general guidance for the statistical and trend analyses. Statements summarizing the results of the trend evaluations and statistical analyses are made at the end of each subsection. Any graphs or plots used for the trend evaluations and statistical analyses should be included in the WSAP.

\section{Site Conceptual Model (Section 2.4)}

This section uses the previously developed portions of Section 2.0 as a basis for discussing the relationship between sources of contamination, affected media, known and suspected routes of contaminant migration, and known and potential human and ecological receptors. The conceptual model is used to do the following:

- Direct data-gathering efforts toward determining the types and magnitude of contamination and the physical and chemical conditions governing contaminant distribution.

- Evaluate current and potential risks to human health and the environment.

- Assist in the selection and evaluation of remedial technologies. 
The conceptual model should provide a level of detail that is similar to the conceptual model presentation in a SOWP, or it should be of sufficient detail for inclusion in a SOWP where one has yet to be prepared. The conceptual model should address the following:

- Description of the site surface, past and current facilities, raffinate ponds, lagoons, and dates of use.

- Process operations, products, and byproducts that have caused, or have the potential to cause, contamination.

- The physical and hydraulic properties of each water-bearing and confining unit.

- The geochemical type and quality of background ground water and surface water.

- The extent of ground water contamination.

- Ground water flow rates and directions.

- Ground water and surface water interactions.

- Current and potential ground water and surface water discharge areas or receptors.

The WSAP does not include unique sampling events specifically for the purpose of risk evaluation or geochemical characterization. The WSAP includes only routine sampling for the activities described in Section 2.2.3 of this guidance document. However, routine sampling events can be guided by and can benefit risk evaluation and geochemical characterization activities.

\subsubsection{Data collection objectives (Section 3.0)}

Section 3.0 of the WSAP presents the regulatory and technical basis for the routine sampling activities. As part of this section, the samples taken for the UMTRA Surface Project and Ground Water Project are identified. There are four reasons (objectives) for collecting data: regulatory requirements, compliance monitoring, site characterization, and other considerations. To maintain a consistent format between WSAPs, every WSAP should contain headings for each of these sections. Sections that do not apply to the site-specific WSAPS are identified as not applicable.

\section{Requlatory Requirements (Section 3.1)}

Title I of the Uranium Mill Tailings Radiation Control Act (UMTRCA) of 1978 142 USC $\$ 7901$ et seq.) establishes the statutory and regulatory framework for the stabilization and control of 24 inactive uranium mill tailings sites ITitle I 
sites). Through the UMTRCA, the U.S. Environmental Protection Agency (EPA) is directed to establish general regulations and standards for the cleanup and disposal of contamination at the sites. Work at the Title / sites is to be performed under the DOE UMTRA Project. The UMTRCA, passed by Congress in 1978 as Public Law 95-604, gives the U.S. Nuclear Regulatory Commission concurrence and licensing authority for the UMTRA Project disposal and cleanup activities. Standards for ground water quality at the UMTRA Title / sites are in 40 CFR Part 192 (1995).

\section{Compliance Monitoring (Section 3.2)}

Compliance monitoring is required for some sites where surface remediation is complete and a disposal cell has been constructed. For those sites, monitoring is required at water quality locations near the downgradient edge of the disposal cell (the point of compliance) and often at background water quality locations. An LTSP and the RAP, if available, are the regulatory documents that identify compliance monitoring locations, frequency, and analytical parameters. The LTSP and RAP must be complied with if approved by the regulatory agencies.

Background water quality is defined as "...the representative water quality after completion of remedial action from a given hydrogeologic unit that has not been impacted by past or present activities at the mill site, or, if impacted by past activities, no longer exhibits the impacts." (DOE, 1986).

If an LTSP or RAP has not been prepared, the WSAP author must recommend the locations for compliance monitoring. Point-of-compliance locations are based on regulatory definitions, results from previous monitoring, and input from the site geochemist and toxicologist. The point of compliance must be adequately monitored, but sampling of closely spaced wells is not necessary if the sampling points are redundant.

Recommendations for adding or deleting wells from routine sampling events may be identified after point-of-compliance monitoring requirements are evaluated. The WSAP can implement the changes if an LTSP, a RAP or another regulatory commitment is not in place. The recommendations for the proposed changes should be documented for the TAC site manager in the form of a memo with the technical manager's concurrence.

\section{Site Characterization (Section 3.3)}

Site characterization may be an iterative process at many of the sites and therefore will require periodic sampling activities. The sampling decisions will require input from the document preparation team, consisting of the site hydrologist, geochemist, toxicologist, statistician, and engineer.

Sampling locations for site characterization are chosen to determine ground water contaminant location, constituent concentrations, background water quality, and baseline water quality. Baseline water quality is "...representative water quality 
from a given hydrogeologic unit that has been impacted by past or present activities at the mill site and is not likely to be affected in the future." (DOE, 1986). Sampling of surface water (such as streams, rivers, seeps, and springs) that may act as areas of ground water recharge or ground water discharge may be necessary for site and aquifer characterization and for the interpretation of surface water and ground water interactions. Sampling of wells other than monitor wells (e.g., domestic wells, non-UMTRA Project monitor wells) and the use of data loggers may also be necessary for site characterization.

Ground water sampling for site characterization can be based on a seasonal schedule that may be related to water availability, water level fluctuations, and surface water and ground water interactions. Performing a trend analysis and comparing water quality to the season and water levels will provide information regarding seasonal water quality fluctuations. Determining the surface water and ground water interactions may also assist in identifying the presence or possible presence of seasonal fluctuations.

\section{Other Considerations (Section 3.4)}

Some of the sites may have special sampling considerations that are part of state, local, or tribal requirements. This section defines those requirements, acknowledges the agency or group requiring the sampling, and specifies the sampling points and constituents to be monitored for those purposes.

\subsubsection{Data quality requirements (Section 4.0)}

Section 4.0 defines the manner in which samples are collected, handled, and analyzed. The objectives for data quality requirements relate to sample collection and preservation procedures, analytical accuracy, and reproducibility of results. A brief narrative and a table prepared for this section of the WSAP define the following information for the proposed sampling:

- Field analytical methods and analytes.

- Laboratory analytical methods and analytes.

- Required quality assurance (OA) samples (field blanks, equipment blanks, duplicates).

- The OA/quality control $(O C)$ level of sample analysis (e.g., Levels $A$ and $B$ for field analyses, Levels $C$ and $D$ for laboratory analyses).

- Detection limits.

- Filtered and unfiltered samples.

- Sample holding times. 
- Sample preservation methods.

- Sampling order (i.e., the sequence of wells and other sampling points).

- Sampling method (e.g., bailer, submersible pump, dedicated low-flow samplers).

- The applicable UMTRA Project SOP for each above element.

- Data loggers (for water level and water quality measurements).

\subsubsection{Sampling plan (Section 5.0)}

Section $\mathbf{5 . 0}$ presents the sampling locations, analytes (including field analyses), and sampling frequencies for the upcoming 2 years. It also includes the projected sampling needs for an additional 5 years (i.e., the 5 years after the detailed 2-year sampling description) and a projected end point for the sampling activities.

Section $\mathbf{5 . 0}$ is a relatively brief section that relies on the data and information presented in the preceding sections for the sampling recommendations. Included are descriptions of the data interpretation methods for the results of the recommended sampling, a summary of the changes from the previous WSAP, and a plan to address anomalous data that may appear as a result of the recommended sampling. This section also identifies samples that are being taken for the UMTRA Surface Project and Ground Water Project.

\section{Sampling Locations, Analyte Selection, and Sampling Frequency}

(Sections 5.1, 5.2, and 5.3)

The monitor well, surface water, and other well (if applicable) locations that will be sampled for the upcoming 2 years are identified in Section 5.1. Also identified are the field and laboratory analytical parameters, including indicator parameters (Section 5.2) and the sampling frequency for each sampling station (Section 5.3). These sections should present only the sampling point designations and recommendations. The information is presented in a narrative form and on a table. The order in which the wells are sampled and the samples taken for the Surface Project and Ground Water Project are identified; filtered and unfiltered samples are specified.

\section{Data Evaluation Methods (Section 5.4)}

This section describes the data evaluation methods planned for the data collected during the period covered by the detailed and projected sampling period (i.e., 2 years plus 5 years). It will likely include trend analyses and geochemical evaluations similar to the methods used to prepare the current WSAP recommendations. Additional methods, as well as an evaluation of potential trends, may be proposed because of an increased database. 


\section{Response to Anomalous Data (Section 5.5)}

This section describes the actions to be taken if the results from the recommended sampling are above or below a range of expected values. It requires the WSAP preparation team to identify the range of expected values for each sampling point and parameter. The parameters include both physical parameters, such as ground water levels, and chemical parameters, such as $\mathrm{pH}$ or sulfate concentrations. Possible actions include immediate resampling or waiting for the next sampling event.

\subsubsection{List of contributors (Section 6.0)}

Section 6.0 lists the names of those who contributed to the preparation of the WSAP. It also lists each person's specific contribution (e.g., document sponsor, document coordinator, primary author, document review, hydrology, geochemistry, toxicology, environmental, engineering design, text processing, graphic design, editing, etc.)

\subsubsection{References (Section 7.0)}

Section 7.0 lists all sources of information cited in the WSAP. The format of each reference follows the standard format for UMTRA Project reports. 


\subsection{SAMPLING FREQUENCY CRITERIA}

A significant aspect of each WSAP is determining sampling frequencies. The following sections provide general guidance on which to base sampling frequency decisions for monitoring ground water and surface water (when needed). The factors to consider in determining sampling frequencies are regulations and site-specific hydrologic conditions. Generally, initial sampling intervals will be more closely spaced than later sampling intervals, to provide a statistical base of information.

Risk assessment requirements and geochemical factors can assist in guiding the routine sampling events described in the WSAP. However, the WSAP does not address sampling conducted specifically for risk assessment or geochemical evaluations. The sampling frequency should provide a sound hydrologic and cost-effective basis to monitor ground water and surface water quality in compliance with water quality regulations and guidance.

\subsection{REGULATORY REQUIREMENTS}

The applicable regulations do not specify sampling frequencies other than those which are "...adequate to define..." background water quality, the location of ground water contamination, the rate of contaminant movement, and disposal cell performance. An approved LTSP or RAP for a site may specify sampling frequencies; however, the sampling interval may be based on time as the only factor. For instance, the sampling interval may be stated as quarterly for the first year, semiannually for several years, and annually thereafter. The specified sampling frequencies may not be the most appropriate for the site-specific hydrologic factors, such as ground water flow rates and well locations. The WSAP provides an opportunity to evaluate site-specific factors to determine the sampling intervals. The sampling intervals recommended in the WSAP will be consistent with the regulations because site-specific factors will be used to determine an appropriate and adequate sampling schedule.

An approved LTSP or RAP defines the regulatory requirements for sampling frequency. If an evaluation of the site conceptual model indicates a different sampling frequency than that specified in the RAP or LTSP, the recommendations should be documented for the TAC site manager in the form of a memo with the technical manager's concurrence, prior to submittal of the WSAP.

\subsection{HYDROLOGIC FACTORS}

\subsubsection{Ground water flow rates}

The relationship between ground water flow rates and sampling intervals identifies the distance ground water has traveled during the time between sampling events. For example, assume a ground water flow rate at a hypothetical site is estimated to range between 13 feet ( $\mathrm{ft})(4$ meters $[\mathrm{m}])$ per year and $140 \mathrm{ft}(42 \mathrm{~m})$ per year. Because of the relatively slow rate of ground water flow, ground water moves only $3 \mathrm{ft}(1 \mathrm{~m})$ to $35 \mathrm{ft}(10 \mathrm{~m})$ between quarterly sampling events, $6 \mathrm{ft}(2 \mathrm{~m})$ to $70 \mathrm{ft}$ 
$(20 \mathrm{~m})$ between semiannual sampling events, and $13 \mathrm{ft}(4 \mathrm{~m})$ to $140 \mathrm{ft}(42 \mathrm{~m})$ between annual sampling events.

Assume also that there is a potential ground water discharge area (e.g., a stream) about $5000 \mathrm{ft}(1500 \mathrm{~m})$ downgradient from the leading edge of contaminated ground water. Based on very conservative contaminant transport assumptions and the range in ground water flow rates, it would take between 36 years and 380 years for the leading edge of the contamination to move from its present position to the potential discharge point. These estimates are very conservative because they assume that ground water originating from the site will actually discharge to the stream. The assumptions overestimate the rate of contaminant transport by assuming that there are no effects from dispersion or attenuation, which would slow the actual rate of contaminant migration. Additionally, the contaminant concentrations could be diluted to below detectable limits prior to reaching the stream.

Traditionally, sampling frequencies have been based on convenient or commonly used time intervals and have not accounted for the distance that ground water travels between sampling events. As demonstrated by the above example, quarterly, semiannual, or annual sampling will not provide a cost-effective means to track contaminant migration. Even during a 1-year period, ground water has not moved a significant distance or a significant percentage of the distance from the source to the potential receptor.

The primary factor for determining sampling frequencies is the distance that ground water travels between sampling events as compared to the distance to an important monitoring point or receptor. A significant distance for ground water flow is one-fourth the distance between two areas of concern. Areas of concern can be the disposal cell and the point-of-compliance wells, or the leading edge of the contamination and a potential receptor.

Using the above example, the areas of concern are the leading edge of contamination and the potential discharge area (the stream). The faster ground water flow rate (resulting in an estimated travel time of 36 years from the leading edge of contamination to the stream) should be used to provide a conservative sampling frequency (i.e., the shortest practical sampling frequency). One-fourth of that distance will be covered in 9 years. Therefore, a justifiable sampling frequency could be once every 9 years. For practical purposes, however, the maximum time interval between sampling events should be 5 years to allow for checking and maintaining the integrity of the wells.

\subsubsection{Water quality}

Previous water quality results and ground water velocity estimates can assist in determining appropriate sampling frequencies. Using data from an UMTRA Project site as an example, sulfate concentrations from three monitoring wells within the contaminated area and three monitoring wells outside the contaminated area were plotted. A schematic of the monitoring well locations and extent of contamination 
is shown in Figure 3.1, and the water quality plots are shown in Figure 3.2. Sulfate is generally a good indicator parameter because 1) it is a byproduct of sulfuric acid, which was used at many UMTRA Project sites throughout the history of mill operation, 2) it is a relatively conservative ion (i.e., it travels at approximately the same rate as ground water flow), and 3 ) the background concentrations of sulfate are usually low.

A visual examination of the water quality plot shows little to no significant variation in sulfate concentrations for the monitoring wells outside of the contaminated zone (903, 910, and 914). Except for one set of lower sulfate values in March 1991. the sulfate concentrations of monitoring wells within the contaminated zone 1906 , 908, and 909) also show little to no variation.

Water levels for all site wells were plotted for the same time period and also showed no significant variation with the exception of one measurement from well 908. The water level in well 908 was about $10 \mathrm{ft}(3 \mathrm{~m})$ lower in November 1990 than preceding and succeeding measurements. Other wells, including those in the same well cluster as 908, did not show a drop in water levels. Because all of the wells are completed within the same water-bearing unit, water level fluctuations in one well would be expected to be expressed in the other wells. Therefore, although it could be correct, the measurement is likely an error. Assuming that the water level measurement from November 1990 is an error, the water levels for the site have remained relatively constant.

The reason for the consistent drop in sulfate concentrations for March 1991 in the contaminated wells is unclear, but sulfate concentrations have otherwise remained relatively constant. The relatively consistent values may have a basis in ground water velocity. Ground water may have moved as little as $52 \mathrm{ft}(16 \mathrm{~m})$ or as much as $560 \mathrm{ft}(170 \mathrm{~m})$ during the 4-year period of record. Therefore, contamination has not migrated significantly, relative to the distance to the potential receptor (the theoretical stream), which is about $5000 \mathrm{ft}(1500 \mathrm{~m})$ downgradient from the leading edge of contamination. The combination of relatively consistent water quality and slow ground water movement would justify a greater period of time between sampling intervals.

\subsubsection{Seasonal effects}

The primary intent of monitoring is to determine ground water quality at the time of sampling. The current results are compared with previous results to detect trends in water quality. An increasing or decreasing trend in contaminant concentrations may indicate contaminant migration, a change in contaminant concentrations (e.g.. dilution, dispersion, adsorption), or a change in background water quality. Changes in water quality may also indicate seasonal fluctuations, which can make the evaluation of long-term trends difficult. Seasonal fluctuations are short-term variations in water quality that are centered around a certain value or closely spaced values and are not indicative of a long-term trend. 

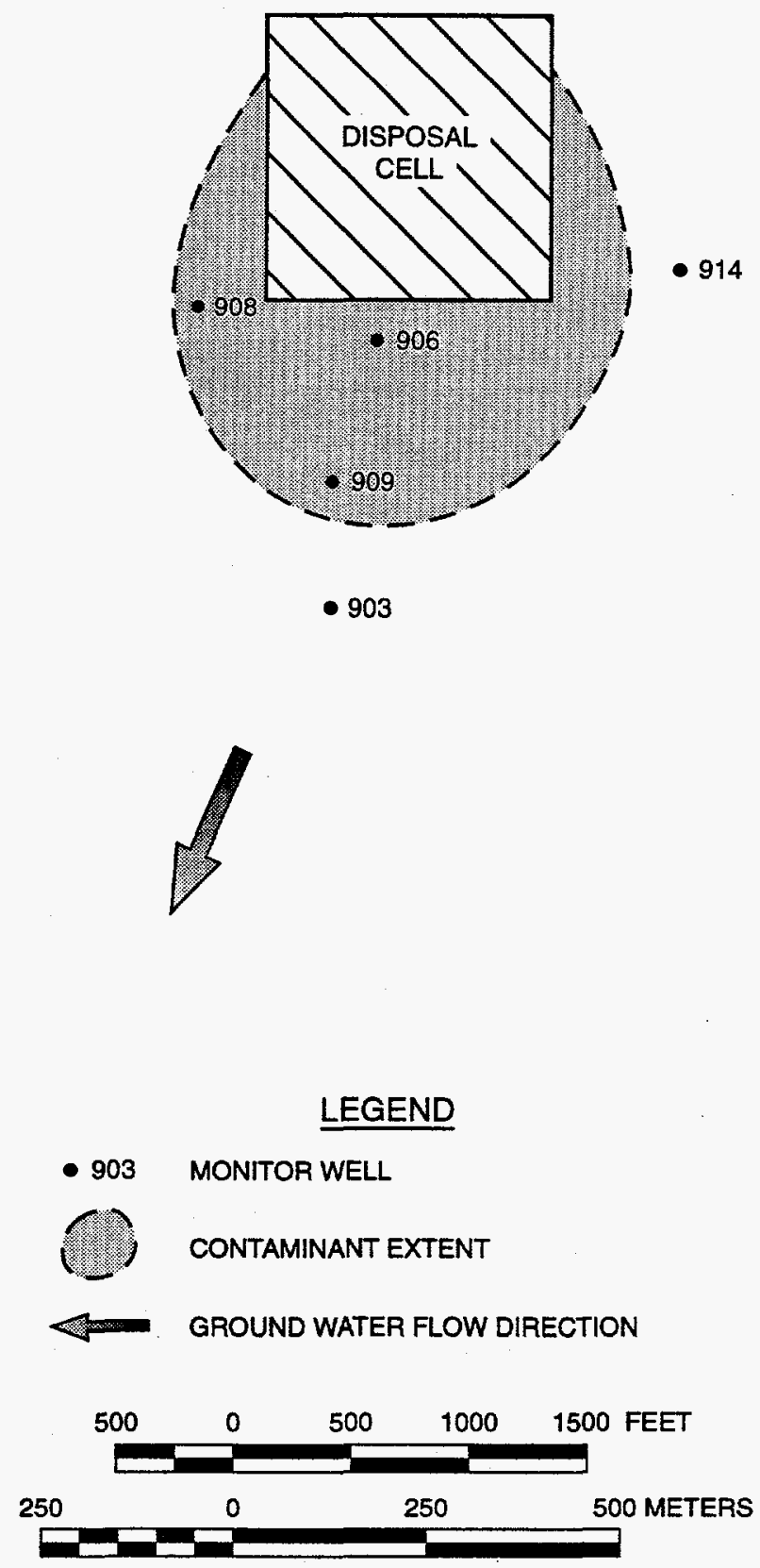

FIGURE 3.1

SCHEMATIC OF MONITOR WELL LOCATIONS AND EXTENT OF CONTAMINATION 


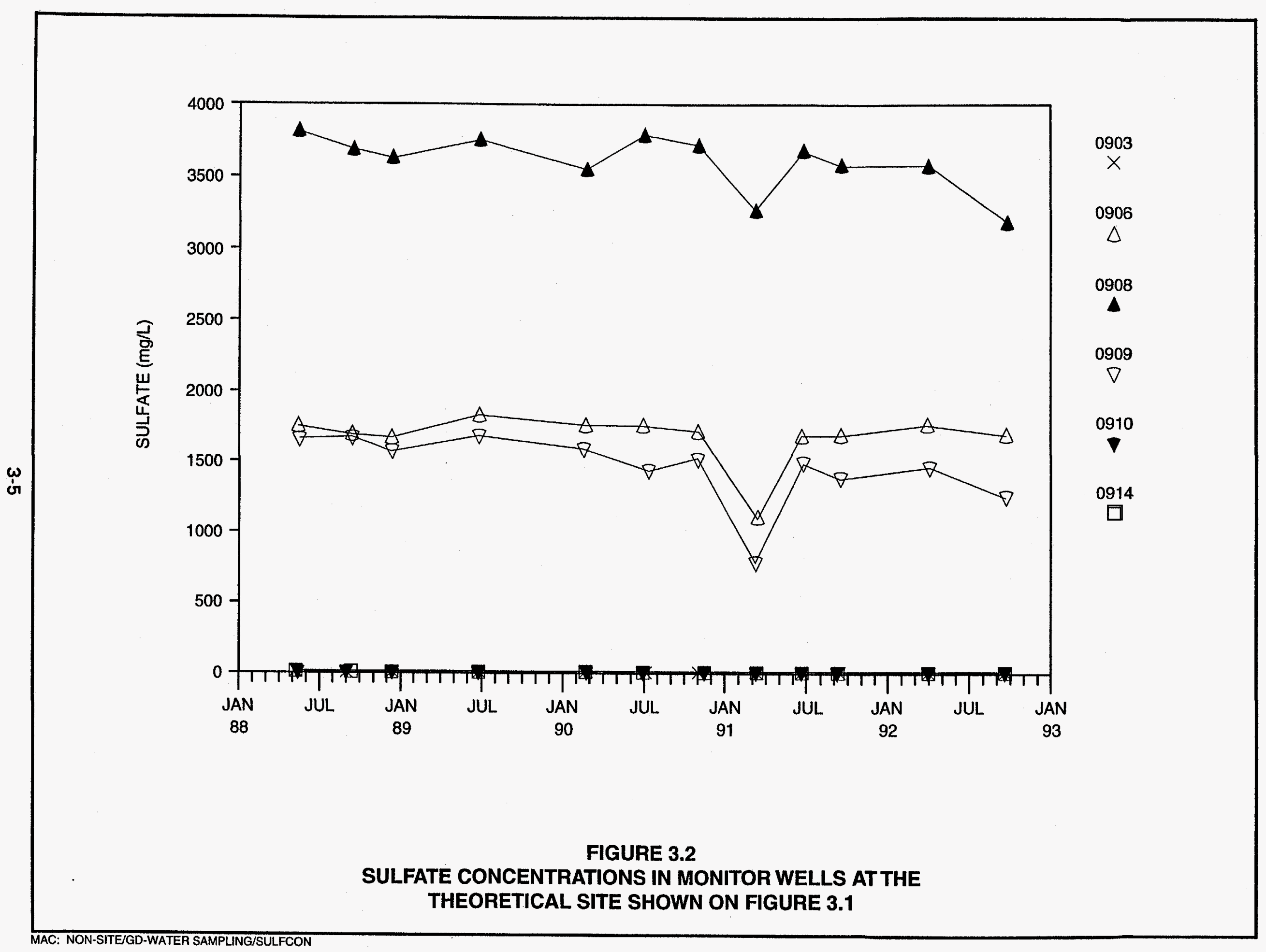


The first step in evaluating seasonal trends is to plot water levels and conservative constituent concentrations versus time (or date) for each well. The data are contained in the UMTRA Project database.

An additional test for trends is to compare rainfall and stream gauging data with water levels (from periodic measurements or data loggers) and ground water constituent concentrations. Stream gauging data will provide daily flow rates, stream stage, and sometimes concentrations of major ions. The stream data are typically available through the U.S. Geological Survey. Rainfall data are collected at large airports and many small airports and are available through the National Oceanic and Atmospheric Administration.

The plots can be statistically evaluated for seasonal or temporal trends. If a trend exists, sampling frequencies can be designed to accommodate the trend. Possible strategies include sampling at the historic high and low concentration periods or sampling at the historical average period. Data loggers should be used for at least 1 year to record seasonal fluctuations, and existing data should be evaluated to determine whether previous samples were collected at high, low, or average periods.

The results from the trend evaluation may not show evidence of seasonal variations or trends. However, that does not mean that seasonal variations or trends do not exist. The database may not be large enough, or the samples may have been consistently taken at average, high, or low periods. If the presence or absence of seasonal trends or variation is an important factor, sampling frequencies or sampling dates may be modified or established or data loggers may be used to test the hypothesis of seasonal variations or trends.

\subsubsection{Surface water sampling}

Some sites may require surface water sampling as part of routine sampling activities. The timing of sampling events for surface water will depend on the purpose of the surface water sampling and on surface water and meteorologic conditions before and during sampling. Springs, seeps, streams, and rivers may flow seasonally depending upon rainfall, snowmelt, and the ground water and surface water interactions within the drainage basin and ground water recharge area. Another factor to consider for larger rivers or streams is control structures such as dams, which can affect flow both upstream and downstream of the structure.

An examination of stream flow records can indicate typical periods of runoff, low flow or no flow. However, brief rain storms can dramatically increase flow, or extended periods of dry weather can reduce flow outside of the typical ranges. Because these conditions are not always known prior to sampling, sampling events must be designed to be flexible.

If the purpose of the sampling event is to determine the quality of ground water discharging into a stream as base flow, then sampling must occur during periods of 
base flow only. Because of the relatively arid conditions at many UMTRA Project sites, low flow may not always indicate base flow (discharge of ground water into the stream). Instead, low flow may indicate a period of time when stream flow is recharging the aquifer.

If the purpose of the sampling event is to determine the quality of surface water runoff within the drainage area, then the stream should be sampled during periods of high surface-water runoff. There may be more than one typical period of high flow, with one period representing snowmelt and another period representing high rainfall. The quality of the runoff may be very different, depending on the source of the runoff. In summary, a surface water sampling program should identify the type of surface water sample to be taken (e.g., surface runoff, base flow), and stream flow and meteorological conditions must be recorded at the time of sampling to assist in interpreting the type of sample obtained. Conditions of surface water bodies should be recorded during every sampling event, even if a sample is not obtained, to guide upcoming surface water sampling events.

Meteorologic conditions and ground water levels are a controlling factor for the occurrence of springs and seeps. The spring or seep conditions should also be recorded during every sampling event, including an estimate of discharge rate.

\subsection{GEOCHEMICAL CONSIDERATIONS}

There are a number of geochemical factors to consider in determining the frequency of routine sampling events. These factors include attenuation, adsorption/desorption, secondary sources in aquifer materials, and reaction kinetics. Generalized applications that could be used at every site are probably not possible, due to the site-specific nature of ground water geochemistry and each site's database. The WSAP author must be aware of the different geochemical reactions affecting sampling frequency and obtain assistance and evaluations from the site geochemist. 


\subsection{SAMPLING LOCATION SELECTION CRITERIA}

\subsection{REGULATORY REQUIREMENTS}

Depending on site conditions and site status, several different types of monitor wells may control sampling requirements. A typical site could require the sampling of background water quality, point-of-compliance water quality, and contaminated water quality. For sites with relatively consistent background water quality relative to location, one background water quality monitoring location is sufficient. Variation due to seasonal effects should be a sampling frequency decision. If background water quality varies with location or if the purpose of sampling is to determine areal variations in background water quality, additional background water quality locations should be sampled.

A minimum of one sampling location at the downgradient edge of a disposal cell should be established for point-of-compliance sampling. One or more sampling locations are appropriate for contaminant definition, if contamination is present.

Typically, several sampling locations for contaminant delineation define the lateral and vertical extent of ground water contamination. Usually only one well of closely spaced wells that monitor the same water-bearing unit needs to be sampled. An additional consideration in selecting wells and well locations is the screen length and gravel-packed interval. Typically, a well with a long screened and gravelpacked interval is not useful for defining vertical contamination.

\subsection{HYDROLOGIC FACTORS}

The characteristics of the water-bearing units must be considered in making sampling recommendations. Nonhomogenous materials or multiple water-bearing units are likely to represent layers of varying porosity, permeability, and ground water velocity. Therefore, they may require more wells to monitor contaminant migration than relatively homogeneous formations or a single water-bearing unit.

The rate of ground water flow is also an important factor to consider in determining monitoring locations and is related to sampling frequency. Well spacing can be considered as time along flow paths. Using the example introduced in Section 3.0, assume that the ground water flow rate is $35 \mathrm{ft}(10 \mathrm{~m})$ per year (Figure 3.1$)$. Wells 906, 909, and 903 monitor the zone of contamination, and the wells are roughly in a straight line that is parallel with the direction of ground water flow. Well 906 is about $200 \mathrm{ft}(60 \mathrm{~m})$ from the edge of the disposal cell, well 909 is about $800 \mathrm{ft}$ $(240 \mathrm{~m})$ from the edge of the cell, and well 903 is about $1300 \mathrm{ft}(390 \mathrm{~m})$ from the edge of the cell.

Using a ground water flow rate of $35 \mathrm{ft}(10 \mathrm{~m})$ per year, it will take approximately 6 years for water to travel from the edge of the disposal cell to well 906 , approximately 23 years for water to travel to well 909 , and approximately 37 years for water to travel to well 903 . These are conservative estimates that do not take 
into account the effects of dispersion and attenuation, which will slow the migration of contaminants. Because the potential receptor (the theoretical stream) is about $5000 \mathrm{ft}(1500 \mathrm{~m})$ (or 140 years) downgradient from well 903 , it is not necessary to determine the exact point in time that the contamination reaches well 903. Therefore, the next sampling interval for well 903 could be many years in the future without the loss of critical information. The sampling frequency would be quite different for a well in a similar location downgradient from the contaminant source, but closer to a potential receptor and within an aquifer with a higher ground water velocity.

\subsection{GEOCHEMICAL CONSIDERATIONS}

As stated in Section 3.4, there are a number of geochemical factors to consider, such as attenuation, adsorption/desorption, secondary sources in aquifer materials, and reaction kinetics. Generalized applications that could be used at every site are probably not possible, due to the site-specific nature of ground water geochemistry and each site's database. The WSAP author must be aware of the different geochemical reactions that may affect sampling, and obtain assistance and evaluations from the site geochemist. 


\subsection{ANALYTICAL PARAMETER SELECTION CRITERIA}

\subsection{REGULATORY REQUIREMENTS}

According to the UMTRCA (42 USC $\$ 7901$ et seq.), the DOE is required to comply with ground water standards for ground water protection and cleanup. Table $\mathbf{5 . 1}$ lists the constituents and maximum concentration limits (MCL) for ground water from 40 CFR Part 192 (1995). To identify the presence and concentrations of regulated contaminants emanating from the site, the concentrations of each constituent listed in Table 5.1 must be initially determined in background and downgradient wells. In addition, analysis for the constituents listed in Appendix I of 40 CFR Part 192 (1995) may be required.

\subsection{CONTAMINANTS OF CONCERN}

For processing sites, including those where tailings are stabilized in place and onsite, contaminants of concern $(\mathrm{COC})$ are those constituents listed in Table 5.1 and Appendix I of 40 CFR Part 192 (1995) that exceeded background, or the MCL, or an alternate concentration limit (ACL). If sufficient volumes of tailings pore fluids were not available for analysis, the initial list of COCs to be measured in processing site ground water would be all the constituents listed in Table 5.1 in addition to the constituents listed in Appendix I of 40 CFR Part 192 (1995) that could be reasonably derived from the milling process.

The initial lists of COCs have been defined at most of the UMTRA Project processing sites. These lists are presented in LTSPs or RAPs. As additional sampling rounds are completed at each processing site, these initial COC lists should be reviewed annually and updated as necessary to reflect the new data obtained. Inorganic COCs that have not been detected in the latest five sampling rounds can also be deleted from the list. Those COCs with MCLs can be deleted from the list if 1) they have not exceeded their respective MCLs for five or more sampling rounds, and 2 ) the most recent analyses do not indicate a consistent increasing trend in concentrations. Proposed modifications to sampling plans presented in LTSPS will require concurrence from the TAC site manager, the technical manager, the DOE, and the U.S. Nuclear Regulatory Commission.

At disposal sites, the lists of COCs to be analyzed are also presented in LTSPs and/or RAPs. As in the case of processing sites, these lists may be based on analyses of tailings pore fluids, information on chemicals used in processing the ore, and/or the results from monitoring at the disposal site. However, the lists presented in the LTSPS and RAPS may need to be modified after the site conceptual model has been evaluated.

Because the main issue of concern at disposal sites is potential leakage from the cell, the list of analytes to be sampled should be heavily weighted toward indicator parameters. These are parameters that travel at approximately the same rate as ground water and are prominent in the tailings pore fluids. Indicator parameters are 
Table 5.1 Ground water standards for UMTRA Project sites"

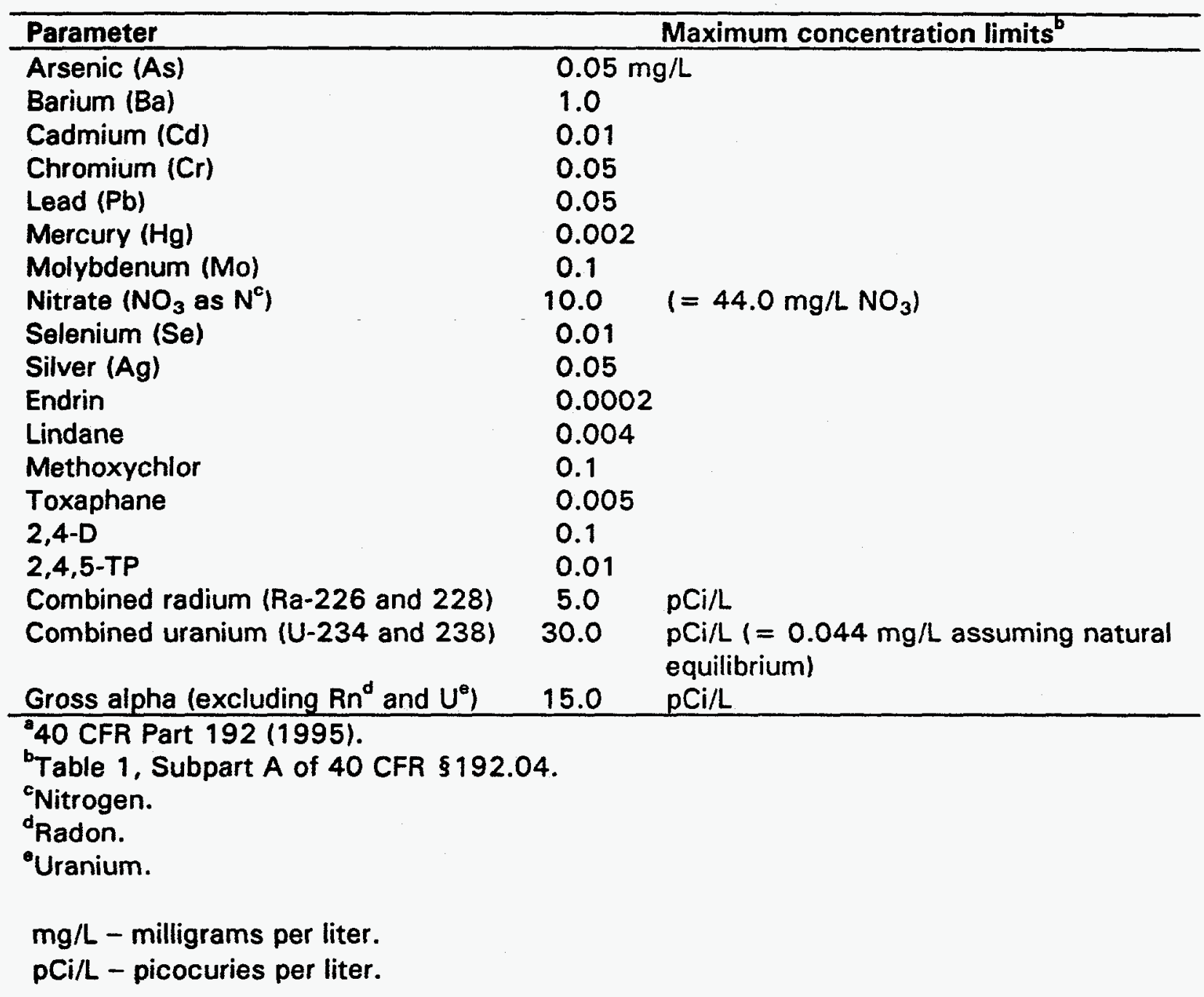


discussed in more detail in Section 5.3. If indicator parameter breakthrough is detected at a given site, the $C O C$ list should be updated in the next sampling round to more clearly reflect the COC list originally presented in the LTSPS and/or RAPS.

\subsection{INDICATOR PARAMETERS}

Indicator parameters are constituents that travel at approximately the same rate as ground water and are present in tailings pore fluids at easily detectable concentrations. They provide the clearest indication of contaminant movement at processing sites and they provide an early warning signal for the migration of COCs from disposal cells. Indicator parameters may not be on the $\mathrm{COC}$ list for a given site but are products or byproducts of mill operations. Examples of indicator parameters are chloride, nitrate, sulfate, total dissolved solids, and specific conductance.

Indicator parameters should be identified at each processing and disposal site by the site geochemist in consultation with the site hydrologist and statistician. Once identified, these parameters should be analyzed in each sampling round at the site. The analytical results obtained in each sampling round should be plotted on concentration-versus-time plots with the other historical data for each well sampled at the site. Deviations from historical trend lines that are outside quoted analytical errors should be analyzed to evaluate whether the deviations are real or artifacts of the analytical or sampling procedures. If analytical or sampling artifacts are not identified, the deviations must be considered real and may call for additional actions (e.g., evaluative monitoring at disposal sites).

\subsection{GEOCHEMICAL REQUIREMENTS}

The geochemical requirements that bear on the selection of analytes for routine sampling events may include one or more of the following:

- The need for complete major constituent analyses (i.e., major anions and cations) and field parameters to allow speciation of contaminant elements by geochemical modeling.

- The need for major constituent analyses and field parameters to allow fingerprinting of ground water types at a site and to potentially provide a basis for identifying natural or non-site-related sources of contaminants.

- The need for specific constituent analyses (e.g., total iron) and/or field parameters (e.g., Eh) to support the ground water protection strategy for the site when it involves a geochemical argument.

- The need for major constituent analyses and field parameters to support potential ground water restoration strategies and transport modeling efforts at the site. 
- The need for complete major constituent analyses for QA/OC purposes, including cation/anion balance and sum of total dissolved solids calculations.

At some UMTRA Project sites, background ground water may have relatively high levels of some of the contaminants generally associated with uranium mill tailings sites. By fingerprinting the various ground water quality types that may exist at the site using major element chemistry, it is often possible to distinguish relatively high levels of COCs in background ground water from elevated levels resulting from site activities. If high levels of COCs in background ground water are suspected at a particular site, historical major element data for the site should be evaluated to attempt to distinguish high background levels of COCs from site-related contamination. This analysis should be conducted by the site geochemist in consultation with the site hydrologist, statistician, site toxicologist, and site engineer, as appropriate. If insufficient data are available for this analysis, additional sampling of major constituents may be warranted.

Ground water protection strategies that involve geochemical arguments may require the documentation of certain geochemical conditions. For instance, if the ground water protection strategy calls for immobilization of the contaminants by oxidationreduction reactions, appropriate data would have to be collected (possibly on a routine basis) to document the existence of sufficiently reducing conditions in the aquifer. This could involve the measurement of dissolved oxygen (DO), oxidation/reduction potential (ORP), and appropriate redox couples such as $\mathrm{Fe}^{3+} / \mathrm{Fe}^{2+}, \mathrm{SO}_{4}{ }^{2-} / \mathrm{S}^{2-}$ and $\mathrm{NO}_{3}{ }^{-} / \mathrm{NH}_{4}{ }^{+}$. Appropriate analyses should be selected by the site geochemist in consultation with the site hydrologist and the site toxicologist. As a minimum, ORP and DO should be measured in appropriate wells in the field during every sampling round at the site.

Although specific ground water restoration strategies have not yet been identified at each processing site, the sampling plan should attempt to anticipate the data needs for evaluating the range of strategies under consideration. The detailed data needs for the different strategies available cannot be detailed here; however, the site geochemist, site hydrologist, and site engineer should consider this aspect in annual sampling requirements.

The QA/OC requirements for analyte selection involve checks of charge balance and mass balance. The charge balance check provides enhanced confidence that the analysis of major cationic and anionic constituents was properly carried out. This is particularly critical in relation to major indicator constituents such as sulfate. Trend analysis of sulfate concentrations commonly show isolated spikes that, on further evaluation with charge and mass balance calculations, are found to be due to previously unrecognized analytical errors. Without the charge and mass balance checks, such spikes could not be rationalized and could lead to problems with regulatory compliance. The evaluation of anomalous data points should be carried out by the site geochemist in consultation with the site hydrologist and the statistician, as appropriate. If a specific indicator parameter shows an erratic historical trend at a given site, one or more rounds of complete major constituent analysis may be useful to rule out an analytical source for the erratic pattern. The 
decision to carry out the major constituent analyses should be made by the site geochemist in consultation with the site hydrologist and data managers. 


\subsection{WSAP FILE CONTENTS}

The format of the WSAP is designed to generate as brief and concise a document as possible, but the basis for the sampling decisions must be provided in the document. The WSAP will contain the results from a number of calculations and assumptions, all of which will not be included in the WSAP but should be maintained in a WSAP file. Copies of each WSAP file are kept by the site hydrologist and the UPDCC.

The WSAP file for a particular site will have subfiles for each year. The subfiles will contain the following items, each in its own folder with the following headings:

- Piezometric surface maps.

- Ground water level graphs.

- Ground water quality graphs.

- Ground water velocity calculations.

- Surface water data.

- Regulatory requirement notes.

- Risk assessment notes.

- Legal access requirements to all wells (including names and phone numbers for site contacts).

- Maps showing detailed physical access (i.e., roads and gates) to all wells.

- Data loggers and data logger records (i.e., tables of data and data plots).

- Annual WSAP review memo. 


\subsection{LIST OF CONTRIBUTORS}

The following individuals contributed to the preparation of this document.

\begin{tabular}{ll}
\hline Name & Contribution \\
\hline A. Miller & Document coordinator, primary author \\
$\begin{array}{ll}\text { A. Holm, J. Carman, D. Erskine, D. Tarbox, } \\
\text { R. Sengebush }\end{array}$ & \\
L. Sanchez, WordCenter, Inc. & Text processing \\
J. Gates & Graphics \\
D. Tamez, D. Thalley & Technical editing \\
\hline
\end{tabular}




\subsection{REFERENCES}

DOE (U.S. Department of Energy), 1993. Remedial Investigation/Feasibility Study (RI/FS): Process, Elements and Techniques, U.S. Department of Energy, Office of Environmental Guidance, RCRA/CERCLA Division (EH-231), Washington, D.C.

DOE (U.S. Department of Energy), 1989. Technical Approach Document, Revision II, UMTRA-DOE/AL-050425.0002, U.S. Department of Energy, UMTRA Project Office, Albuquerque Operations Office, Albuquerque, New Mexico.

DOE (U.S. Department of Energy), 1986. Guidance for UMTRA Project Surveillance and Maintenance, UMTRA-DOE/AL-350124.0000, U.S. Department of Energy, UMTRA Project Office, Albuquerque Operations Office, Albuquerque, New Mexico.

Freeze, R. A., and J. A. Cherry, 1979. Groundwater, Prentice-Hall, Inc., Englewood Cliffs, New Jersey.

JEG (Jacobs Engineering Group Inc.), n.d. Albuquerque Operations Manual, standard operating procedures, prepared by Jacobs Engineering Group, Albuquerque, New Mexico, for the U.S. Department of Energy, UMTRA Project Office. Albuquerque Operations Office, Albuquerque, New Mexico.

\section{CODE OF FEDERAL REGULATIONS}

40 CFR Part 192, Health and Environmental Protection Standards for Uranium and Thorium Mill Tailings, U.S. Environmental Protection Agency (1995).

\section{UNITED STATES CODE}

42 USC $\$ 7901$ et seq., Uranium Mill Tailings Radiation Control Act, November 8, 1978. 